\title{
The temptations of politics: Jesus' temptation and ours in John Milton's Paradise Regained
}

\section{Stephen J. Plant}

Dr Stephen J. Plant is Dean and Runcie Fellow at Trinity Hall, Cambridge.

Cambridge, UK sjp27@cam.ac.uk

This paper aims to shed light on the ways in which politics can be a site of temptation for Christians. In the first part, it explores the circumstances in which John Milton wrote Paradise Regained, printed in 1671. The poem may be understood, in part, as Milton's reflection on the failed politics of the Republic in which he had played a leading role as a civil servant and one of the Republic's chief propagandists. The second part of the argument offers a reading of Milton's poetic account of the story of Jesus' 40 days in the wilderness, which interprets Jesus' temptations politically as a series of attempts by Satan to deflect Jesus' messianic identity, revealed at his Baptism, from its true course.

KINGDOM OF GOD • JOHN MILTON • POLITICS • SATAN • TEMPTATION 


\section{Introduction}

Churches in the Holiness tradition from the outset placed a premium on extending the reach of the gospel into politics. For the most part, the motivation for political campaigns by Methodists, Salvationists and others was pastoral and moral; but good intentions were often not enough to keep Christians from making a hash of political engagement. For example, Methodists played a lead role in the Temperance movement that led, in 1919, to the Eighteenth Amendment to the Constitution of the United States, which prohibited the manufacture and sale of intoxicating beverages; the amendment remained in place until 1933. One may plausibly claim that Prohibition was 'the high water mark of Methodist national influence [in the USA]. Methodism led the legislative campaign and effectively, if temporarily, imposed a distinctively Methodist moral absolute on the entire nation.'1

One theologically acute outside observer noted in 1939 that Methodists in particular and others too had had to learn the painful lesson from the failure of Prohibition that 'the imposition of Christian principles on the life of the state led to catastrophic collapse ... A "Christian" law had brought disaster for the state and had to be rescinded - with the consent of the churches.'2

Similar examples from Holiness churches in several countries can be given, but the story is often uncannily similar in each case. ${ }^{3}$ Holiness churches, in each generation and context, have had to learn again the lesson that politics lays temptation in the path of even the best-intentioned Christian. Holiness traditions are particularly exposed because of their conviction that holiness is to be worked out socially.

The first step in resisting any temptation is properly to identify it. In this paper I aim to offer some help in identifying political temptation in dialogue with an unexpected source: John Milton's poetic exploration of the story of Jesus' temptation by Satan in the wilderness in Paradise Regained. This story has exerted a powerful influence on the literary imagination. In both Nikos Kazantzakis' The Last Temptation of Christ ${ }^{4}$ and Jim Crace's Quarantine, ${ }^{5}$ the temptation story is the lens through which the identity of their respective Christs is focused. However, in both these cases, under the persistent influence of Freud, the story revolves around sexual desire as the underlying cause of all human pathologies. In Milton we find an older, even more compelling, political interpretation of Jesus' temptations. Read with Milton, the story of Jesus' wilderness temptation is less a moral primer on personal temptation and more 
a profound lesson in how to avoid political temptations; less about individual bodily frailties than about potential collective failures when churches engage with the body politic. Politics, for the purposes of this essay, include the science and practice of government, but extend outwards to encompass also the life of society in its broadest sense and reflective engagement in shaping social organisms.

It might be possible to make a case for the importance of Milton to the political temptations faced by Methodists and others by pointing out the importance of Milton to John Wesley, who often cited Paradise Lost in his letters and even, though rarely, Samson Agonistes. One might also make a case for Milton's importance as an exemplar of a Dissenting theology that would come, a century after his death, to make up one of several theological streams flowing into the Methodist river. However, I doubt whether either case can be made very strongly. Neither do I want to suggest that the political challenges faced by Milton and others in the middle of the seventeenth century bear any striking likeness to those faced by Christians today that make them especially instructive. As will become plain in what follows, Milton's context was very particular. My own aims are rather simple. I want, first, to take account of the historical and political context of Paradise Regained in order to support a claim that in the poem Milton is reflecting in dialogue with the Bible on his own experience of political temptation. Having sketched in this context, I want to approach Milton's poem as a particularly acute and poignant reflection on Jesus' temptation, one that seeks to apprehend Jesus' identity and vocation in political terms that - as one among several aims in a complex poetic text serves to provoke Christians to think theologically and spiritually before they act politically. Milton's poem cannot tell a contemporary Christian what to do in exercising her political calling. Not only is it foolish to imagine that Milton could have anticipated every new circumstance Christians have subsequently faced; for all its power, Paradise Regained does not have the theological authority of the gospel on which it draws. But by shedding light on the temptations that Jesus faced, Milton can also illuminate the temptations a contemporary Christian faces in politics.

\section{The context of Milton's Paradise Regained}

To help a shortsighted Church properly identify the nature of political temptation, I am proposing, then, that we follow a blind guide. Written 
between 1667 and 1670, Paradise Regained is one of the most profound treatments of the temptation of Jesus in any language or genre. It was the last poem John Milton published, and some knowledge of the circumstances in which it was written is essential to understanding its content. ${ }^{6}$ Milton became blind sometime around $1652,{ }^{7}$ which meant Paradise Regained was dictated to an amanuensis. Milton's blindness proved to be a double-edged sword. On the one hand, as he noted in Sonnet XVI on his blindness, his eyes' spent light meant his 'one talent which is death to hide' - that is, his talent for words 'Lodged with me useless'. ${ }^{8}$ On the other hand, following the restoration of the monarchy to England in 1660 it may have been Milton's blindness that saved him from a long spell in prison - or even worse.

For a substantial portion of his working life Milton was not a poet but a civil servant at the centre of national political life. In March 1649 the new republican Council of State offered Milton the post of Secretary for the Foreign Tongues. ${ }^{9}$ In this role Milton played a key part in the Commonwealth's dealings with foreign powers. Milton's reputation as one of the finest scholars in England was certainly one reason why he was suddenly in demand. His fluency in Latin the international diplomatic language - was a useful tool for a regime keen to placate neighbouring monarchies that might give succour to the Royalist cause in Britain and Ireland. But the Council of State also recognised in Milton a committed partisan in its cause, someone with an established record as a firstclass polemicist and apologist able to represent the republic to European monarchs with good reason to be suspicious of English radicalism.

The heady mix of religion and politics that had brought the new English Republic into being had long been Milton's chief concern. He had involved himself early on in these unfolding disputes by becoming a pamphleteer opposing episcopacy and supporting the Parliamentarian cause. Episcopacy as a form of Church government, he thought, encouraged clergy to pursue high office for mercenary reasons or for reasons of personal vanity. Milton's suspicions about 'prelatical episcopacy' in the Church were of a piece with his suspicions about monarchical rule in the State and it was on his own initiative, though in his official role, that Milton undertook in 1649 to write a defence of regicide, his Eikonoklastes, ${ }^{10}$ which was printed just two weeks after King Charles I had been beheaded. In the 42-page pamphlet he avoided mentioning Charles by name, since he thought the King's guilt or innocence was for others to decide. Instead, as William Parker puts it, Milton's 'own concern was to justify the judging.'11 Milton, then, was not merely a hired pen of the Republic but its principled supporter. He began his service believing in the possibility that, in 
the Commonwealth, he was helping to build God's kingdom on earth. Yet, over the course of his many years' unflinching service to the Republic and subsequently to Oliver Cromwell as its Lord Protector, Milton's optimism drained out of him slowly but surely like sap from an injured tree. In 1641, as Christopher Hill points out, Milton was full of millenarian hope and wrote of Christ's return in terms of a 'shortly expected king'. In 1649 he was still writing of a 'kingdom which we pray incessantly may come soon'. Yet by 1651 , with growing experience of the realities of political office, his hopes were diminishing and he now merely 'looked for' the coming of Christ. Eight years later with Oliver Cromwell unexpectedly in his grave and rumours circulating of an earthly monarch's imminent return, Milton's millenarian aspirations were replaced by the more muted conviction that Christ's 'spiritual kingdom' is 'able, without worldly force, to subdue all the powers and kingdoms of this world, which are upheld by outward force only' ${ }^{\prime 2}$

Any hope Milton had that the Commonwealth would establish God's kingdom died the death of a thousand cuts in the mundane realities of political office, its compromises and retreats, its petty jealousies, its ideological failures, and the human frailties of its leaders. He learned to recognise that if paradise were to be regained it would not come at the hands of generals and politicians but from the hands of God alone. Milton came to the story of Christ's temptations in light of the failure of Christians - himself included - to resist political temptation. This failure had catastrophic consequences for the three kingdoms of England, Scotland and Ireland and all the blood spilt came to nothing with the restoration of King Charles II to the throne. This outcome also came with considerable personal danger. On 8 May 1660 Charles II was proclaimed King. Prominent republicans quickly made themselves scarce. ${ }^{13}$ Blind as he was, Milton followed their example. On 14 May the arrest was ordered of all those present at the court that had condemned Charles I to death. Milton had not been a member of the court but had been the official apologist of the court's right to judge a king; but still, his name did not appear on any arrest warrant. Behind the scenes, Milton's friends worked cautiously on his behalf and now his blindness proved helpful. In a placard published in London, Milton was listed among examples 'of God's Judgments on some Eminent Engagers against Kingly Government': he had, its authors claimed, been 'struck totally blind' for writing the Eikonoklastes. Milton's friends were able to argue that those whom God has punished need no further human justice enacted upon them. Among those working on his behalf was the poet Andrew Marvel, who sat for the constituency of Hull in the House of Commons and was able to use his access 
to the corridors of power to help keep Milton from the scaffold. In September, Milton reappeared in London; but he had returned too soon: he was arrested and jailed. But Marvel and others had done their work well; Milton was released after only a couple of weeks and, on 15 December, his annus horribilis concluded with his inclusion on the indemnity bill, which had the force of a royal pardon. 'What', William Parker asks,

... did Milton learn? What did twenty years of struggle, crowned so tragically, teach him about God and man? The answer of course is contained in the great poems, and if one wishes to know that answer in its subtlety and its totality, there is no substitute for thoughtful reading of Milton's words. ${ }^{14}$

Inevitably, the reception history of Milton's works reveals not one univocal 'thoughtful reading', but several. Before the seventeenth century was out attempts to co-opt Milton to various political causes had begun. In 1698 John Toland, for example, was claiming Milton for the radical republican cause, writing that Paradise Lost was intended 'to display the different Effects of Liberty and Tyranny'. ${ }^{\prime 5}$ Among Milton's most influential recent interpreters, however, Stanley Fish has advised caution about interpreting Milton's later works as interventions - subtle or not so subtle - in particular political events, preferring to understand the undoubted political aspects of the poems as reflecting Milton's interior disposition, his'politics of being. ${ }^{16}$ What is clear is that the strict censorship that operated under Charles II was a factor that no critic can fail to take into account. Ironically, it is to that censorship that we owe the preservation of a text that sheds considerable light on Milton's theology in general. ${ }^{17}$ In 1823 a bundle of papers written by Milton when he was Secretary of Foreign Tongues turned up in a state archive in London. Among them was a manuscript, in Latin, titled De Doctrina Christiana. The handwriting in the manuscript came from two hands, subsequently identified as those of Daniel Skinner and Jeremie Picard. Very soon after Milton's death in 1674, Skinner, who was Milton's pupil and friend, attempted to publish the work in Amsterdam, Europe's most tolerant city, but he did not succeed. It was handed over, therefore, to the English authorities who, nervous of its impact, buried it in the archive. Because the manuscript is not in Milton's own spidery handwriting (how could it be - he was blind), some doubt remains about the extent to which the work is Milton's and the extent to which his two amanuenses had a role in its production. But assuming De Doctrina Christiana ${ }^{18}$ to be completely or very largely Milton's work, the manuscript gives a very clear sense of his 
mature theological views. The book, which is over 700 pages in translation, consists in two books. Book I, which at 33 chapters is the longer part, is concerned with 'the knowledge of God', while Book II, weighing in at 17 chapters, deals with 'the service of God', a classic Protestant structure. Each chapter consists largely of collections of biblical verses or passages relevant to a particular topic, accompanied by'editorial' comments. In Book I, Chapter XXX, 'Of the Holy Scriptures', we get a clear sense of the theological understanding of the role of the Bible in Christian theology that determined the method Milton followed in the Treatise as a whole. Milton believed the Scriptures to have been composed by the prophets, apostles and evangelists 'under divine inspiration'. ${ }^{19}$ They were written 'for the use of the church throughout all ages, as well under the gospel as under the law,'20 meaning that God's intention is that they be permanently authoritative for humankind. The Bible is, however, given to any reader to interpret its meaning:

From all these passages [ie, passages cited from the Bible] it is evident, that the use of the Scriptures is prohibited to no one; but that, on the contrary, they are adapted for the daily hearing or reading of all classes and orders of men ... The Scriptures, therefore, partly by reason of their own simplicity, and partly through the divine illumination, are plain and perspicuous in all things necessary to salvation, and adapted to the instruction of the most unlearned, through the medium of diligent and constant reading. ${ }^{21}$

For Milton it is not the case, however, that each reader is authorised to 'make up' the meaning of what she reads herself; rather, each text has its plain sense and no'passage of Scripture is to be interpreted in more than one sense..22 As Ken Simpson has pointed out, Milton's understanding of the 'twofold scripture' of the Bible and the inner witness of the Holy Spirit was intimately connected with his ecclesiology and his literary method in Paradise Regained. ${ }^{23}$

Certainly, Milton accepted that for those who would interpret the Scriptures in public, that is, those tasked with teaching and preaching, interpretation is aided by academic skills and disciplines such as

knowledge of languages; inspection of the originals [ie, original manuscripts]; examination of the context; care in distinguishing between literal and figurative expressions; consideration of cause and circumstance, of antecedents and consequents; mutual comparison of texts; and regard to the analogy of faith. ${ }^{24}$ 
Yet in spite of a positive role for scholarly and rhetorical education, Milton iterates forcefully that '[e]very believer has a right to interpret the Scriptures for himself inasmuch as he has the Spirit for his guide, and the mind of Christ is in him.25 The role given by Milton to the living witness of the Spirit was crucial and preserves his use of the Bible from biblical literalism. The rule and canon of faith, that is, the only warrant possible for doctrinal statements and for Christian living, Milton concluded, is the 'twofold Scripture; one external, which is the written word, and the other internal, which is the Holy Spirit, written in the hearts of believers. ${ }^{26}$ Even so, the remarkable story of De Doctrina Christiana should not lead us to think that in his later poems Milton evaded the censor by excluding politics altogether. Milton's later poems 'could nevertheless carry political meaning, working allusively and indirectly.'.

\section{Paradise Regained}

Milton's first and most striking creative interpretive decision was to attend to the temptation story rather than the Passion narratives as a key event in the unfolding drama of salvation. In 1667 Milton had published Paradise Lost (twelve books long, in contrast with the four of Paradise Regained), in which his stated aim was to 'assert Eternal Providence, /And justify the ways of God to men.'28 Paradise Lost ended in tears, literally, with Adam and Eve walking slowly hand in hand out of Eden's garden and into the wilderness. As if it were the second half of a palindrome, therefore, Paradise Regained begins in the wilderness and ends with a feast. Paradise Regained recapitulates the plot of Paradise Lost just as Christ recapitulates the temptation of Adam, as Milton sets out to:

... sing

Recovered Paradise to all mankind,

By one man's firm obedience fully tried

Through all temptation, and the Tempter foiled

In all his wiles, defeated and repulsed,

And Eden raised in the waste wilderness. (PR I:2-6)

As I have already hinted, Milton's decision to place the temptation story in the foreground of the drama of salvation was theologically atypical. More usual are understandings of redemption that emphasise either the incarnation of Jesus as a whole or that focus more narrowly on his Cross and Resurrection. The 
approach taken in Paradise Regained was not, however, without precedent: in arguing against Marcion and other Gnostic heresies, Irenaeus too made Jesus' victory over Satan's temptation central for the economy of salvation by which Satan's victory over Adam is recapitulated and reversed in Christ's victory over temptation. ${ }^{29}$ Yet while Irenaeus presents us with a cosmic drama in which a bellicose Christ emerges victorious, Milton's Jesus is consistently characterised by understatement, by his disdain for the struggle and by patience and calm.

\section{New Testament accounts of Jesus' temptation in the wilderness $^{30}$}

All three Synoptic Gospels report that at the beginning of his ministry Jesus was in the wilderness for 40 days - a period of time that was an intentional echo of the people of Israel's 40 years in the wilderness following their Egyptian captivity. In each of the Synoptic Gospels Jesus' time in the wilderness follows an account of his Baptism by John in the River Jordan (an event also described, unlike the temptation itself, in John's Gospel). In Mark, following the Baptism, Jesus sees the Spirit descending on him as a dove and hears a voice identifying him as God's beloved Son in whom God is pleased. Both Matthew and Luke almost certainly knew and used Mark's Gospel in their accounts of the Spirit's descent and God's statement to Jesus concerning his Sonship and God's pleasure. In each account, then, Jesus is anointed by the Spirit and is made fully conscious of his identity as God's Son and of the pleasure given to God by his obedience. Luke amplifies the insight Jesus' Baptism affords into his identity by inserting Jesus' genealogy between his Baptism and temptation, while Mark and Matthew savour the drama of Jesus moving abruptly from crowded riverbank to empty wilderness. What is evident in each of the Synoptic Gospels is that the temptations follow upon the clearest possible announcement that Jesus is God's Son. Whatever else is going on in the Synoptic Gospels, the devil is not tempting Jesus with doubt that he is God's Son; he is, instead, testing the kind of Son Jesus will be. The test is not of Jesus' identity but of the particular pattern his vocation will follow.

In Mark's account of the wilderness temptation the bare bones of the story are all present: the role of the Spirit in driving Jesus into the wilderness, the length of time spent there, the temptation by Satan, and the concluding ministry of the angels to the hungry Jesus. In addition to Mark, Matthew and Luke share another source in which three temptations are detailed, though Luke differs 
from Matthew with respect to the order of the second and third temptations. All three Synoptic Gospel writers use the same word 'peirazomenos', ${ }^{31}$ which may be translated 'he was tempted'. It is important to be clear about what this word would likely have meant to the first readers of the Gospels. Its gist is 'to make an attempt' or 'to test someone', a 'trial', a 'proving', an 'experiment'. The trial can be from external causes (such as a bodily condition; see Galatians 4:14) or inward; it can be a test of a person's fidelity, integrity or virtue. ${ }^{32}$ It is seldom used outside the New Testament and Christian writings. Temptation can be an enticement to sin, but that does not by any means exhaust its meaning.

\section{The first temptation: stones to bread}

Milton follows the basic structure of Luke's account of the Baptism and temptation, though omitting the genealogy. Elements include the Baptism, the Spirit's role in leading Jesus out into the wilderness, a 40-day period of fasting (that the Gospel writers certainly understood in relation to the 40 years in the wilderness of the people of Israel after leaving Egypt), the 3 temptations according to Luke's order, and the angelic ministry to Jesus. But Milton also exercised considerable freedom in his poetic re-narration of the story. For example, while Milton follows the order of the temptations in Luke's Gospel, he follows Matthew in telling us that the temptations took place at the end Jesus' 40-day fast (PR I:309), while Luke tells us Jesus was tempted throughout the duration of his 40-day fast. Milton also adds several new episodes. In the first of these additions, following a brief description of the Baptism by the poem's narrator, 'the Adversary' summons his 'gloomy consistory' to address the crisis that the coming of God's Son represents. The political aspect of the crisis is immediately plain in Satan's outline of it:

... well ye know

How many ages, as the years of men,

This universe we have possessed, and ruled

In manner at our will th'affairs of Earth. ( $P R$ I:47-50)

Unless Jesus can be deflected from his vocation he will replace the satanic council as the world's effective ruler. Milton further innovates in embellishing the first of Jesus' temptations with an account of a ruse as the devil appears in the guise of 'an aged man in rural weeds' (PR I:314). In spite of this added colour, the sense of the first temptation as it appears in Luke is tweaked only 
slightly in Paradise Regained. The devil, in the guise of a swain, hints at his own material poverty before suggesting that if Jesus be the Son of God, he:

...command

That out of these hard stones be made thee bread. (PR I:342-343)

Milton's subtle interpolation into the gospel narratives hints that if Jesus were to perform the miracle then not only his own but the poor swain's hunger would be satisfied:

So shalt thou save thyself, and us relieve

With food, whereof we wretched seldom taste. (PR I:344-345)

In the first temptation, just as much as in the others, temptation to turn stones to bread is subtly linked to Jesus' messianic calling. Milton's Satan enhances the temptation that Jesus satisfy his own hunger with the promise that in doing so Jesus would selflessly satisfy the physical hunger of the poor. What Messiah would not want to feed the hungry poor? Satisfying hunger is one thing, but central to Milton's Jesus is that one take notice of whose hands are giving the bread we eat. When food is later offered from God at the hands of angels ( $P R$ IV:586-594), Jesus gladly takes it; but he will not accept food from the hands of Satan, to whom the gift does not truly belong.

To receive food but fail to be aware that God alone is the true giver of all good things is to lack something; it is to remain spiritually hungry. It is perhaps this that makes it so clear that the hungry peasant is the devil in disguise. Jesus has not been fooled:

Think'st thou such force in bread? Is it not written ...

Man lives not by bread only, but by each word

Proceeding from the mouth of God ... (PR 1:347-350)

Both Matthew and Luke tell us that Jesus was really hungry and Milton agrees. The fact that Jesus really hungered is more than a narrative flourish; it touches on an essential question in Christology: was Jesus fully human as well as fully divine? One possibility entertained in some early Church commentary on the temptations was that Jesus used his divinity to suppress his appetite or, in some other way, was going through the motions of being tempted without being in any real danger of losing control. St John Chrysostom (c. 347-407), for 
example, said that Jesus fasted in order to instruct Christians in self-discipline, taking on hunger like a wrestling teacher demonstrating technique to his pupils on the training ground..$^{33}$ Chrysostom, indeed, even suggested that God is able to nourish a man by his Word alone. The christological danger in this is that Jesus would then only seem to be human. But for Milton, as it appears was the case for Matthew and Luke, Jesus' hunger is real hunger. To emphasise this, Milton has Satan conjure up not bread alone but a feast that the poet describes in fabulous detail (PR II:337-367). Jesus' answer to the devil in Milton's account is, however, concerned not merely with physical hunger, with a fleshly desire to fill one's belly - which was another common reading of the first temptation in the early Church. Jesus' answer to the devil burrows beneath the surface of physical hunger to a deeper insight:

But now I feel I hunger; which declares

Nature hath need of what she asks; yet God

Can satisfy that need some other way,

Though hunger still remain ... (PR II:252-255)

For Milton Jesus' physical hunger, though it is a genuine and urgent human need, is not the only kind of hunger that matters. When Satan presses further at the level of his physical need Jesus becomes explicit about the deeper issue at stake:

'How hast thou hunger then?' Satan replied.

'Tell me, if food were now before thee set,

Wouldst thou not eat?' 'Thereafter as I like

The giver', answered Jesus ... (PR II:319-321)

Satan was well aware that tempting Jesus at the level of his human flesh was unlikely to be a successful strategy. Early in Book II (PR II:150-153) the dissolute demon Belial suggested to Satan that he 'Set women in his eye and in his walk' and was summarily dismissed. Satan knows that Jesus will not give in to his natural physical desires. Milton's understanding of the first temptation speaks directly to the deep-rooted Christian commitment to feed the hungry and fight against the complex causes of hunger. Milton sets out from the reality of hunger. Hunger is real and it really matters. Milton's Jesus at no point says that feeding a hungry person is anything but a good act. In spite of this, Jesus is not prepared to turn stones to bread if it comes at the price of forgetting that bread comes from God. Human beings have an even more basic hunger than physical 
hunger, a hunger to live by the word that proceeds from the mouth of God. To be clear: this is not intended to diminish the awful horror and power of genuine famine. Famine is a dreadful evil that dehumanises those who experience it. Satisfying a hungry person's need for bread is to meet their most urgent need, but it is not to satisfy their only need or even their most basic need. Human well-being includes bread, but it cannot be reduced to it. The first temptation is, initially, a temptation to reduce human flourishing to the satisfaction of material needs.

The first temptation is also, finally, a temptation about whether it is ever right to pursue political power for the sake of the poor if that incurs a moral debt. In the poem, the background to this question is found in another of Milton's embellishments to Luke's narrative. At the beginning of Book II Milton cuts back to the newly baptised at the Jordan and listens in to their conversation. The putative disciples speak among themselves of their messianic hopes:

Our expectation? God of Israel,

Send thy Messiah forth; the time is come;

Behold the kings of the earth, how they oppress

Thy chosen ... (PR II:42-45)

The disciples' narrowly political understanding of the Messiah serves as a harsh background on which to project the harder and lonelier political path, which Jesus chooses to take. Bluntly, the disciples are looking for a political figure to drive the Romans from Israel but in Jesus they are given a very different kind of Messiah, one who is Emmanuel, God with us. Thus when, at the beginning of Book III, Satan concludes his remarks about Jesus' refusal to turn stones to bread Jesus calmly replies:

Thou neither dost persuade me to seek wealth

For empire's sake, nor empire to affect

For glory's sake, by all thy argument. (PR III:44-46)

This remark, leading away from Jesus' insistence that none of the world's material goods are Satan's to give, serves as an effective bridge to the second temptation. 


\section{The second temptation: political power}

In Luke, the second temptation is Satan's offer to Jesus of all the kingdoms of the world if Jesus will worship him. For the second temptation Milton's Satan abandons subterfuge and, without his unconvincing disguise, tells Jesus precisely what he will now do.

But I will bring thee where thou soon shall quit

Those rudiments, and see before thine eyes

The monarchies of the earth ... (PR III:244-246)

Now Milton innovates by breaking this offer into two distinct components, each with its own subtle attraction and each thoroughly political in character. The first component is to tempt Jesus in relation to the rule of one very particular kingdom: the kingdom of Israel that had once been ruled by Jesus' ancestor David. Satan points out that Jesus will be King of the Jews in name only without his, Satan's, intervention:

Endeavour, as thy father David did,

Thou never shalt obtain ...

But say thou wert possessed of David's throne

By free consent of all, none opposite,

Samaritan or Jew; how couldst thou hope

Long to enjoy it quiet and secure

Between two such enclosing enemies,

Roman and Parthian? ... (PR III:353-362)

If Jesus is to be king of Israel, he will need also to become ruler of an alliance of powerful nations to ensure the regional geopolitical stability necessary for peace and prosperity. But in his reply Jesus answers that the kind of kingdom of which he is king has no interest in political strategies of this kind:

Before mine eyes thou hast set, and in my ear

Vented much policy, and projects deep

Of enemies, of aids, battles, and leagues,

Plausible to the world, to me worth naught. (PR III:390-394)

The second component of the second temptation now enters in. Jesus is transported, at the beginning of Book IV, to Rome. There, pointing out its old 
and lascivious emperor (the emperor Tiberius), Satan challenges Jesus to make Rome an altogether better place:

Might'st thou expel this monster from his throne Now made a sty, and, in his place ascending,

A victor-people free from servile yoke! (PR IV:100-103)

Once more, subtly interwoven with the temptation directed to any desire Jesus might have for glory, is a temptation to accept the kingdoms of Israel and of Rome to effect a greater good in the liberation of Jews from their servile yoke. What Messiah would not want peace and prosperity for the Jewish people? Jesus is being tempted to be precisely the kind of Messiah for which the disciples at the beginning of Book II expressed their hope on the banks of the Jordan.

As with the first temptation, there are two distinct aspects of the temptation that Milton has Jesus resist. Jesus' response is not to deny his kingship but to redefine the nature of his kingship and to refuse to give any indication of how it will come about:

Know, therefore when my season comes to sit

On David's throne, it shall be like a tree,

Spreading and overshadowing all the earth,

Or as a stone that shall to pieces dash

All monarchies besides throughout the world

And of my kingdom there shall be no end:

Means shall there be to this; but what the means

Is not for thee to know, nor me to tell. (PR IV:146-151)

Taken as a whole, the second temptation is therefore not the temptation to rule as such - since kingship is Jesus' proper calling as God's Messiah - but the temptation to rule in a way that is false to the true nature of the kingdom of God. The temptation concerns the end proper to Jesus' calling and also the means to that end. Only after this conversation has taken place does Milton have Satan reveal the condition for his offer of the earthly kingdoms over which he claims authority.

On this condition, if thou wilt fall down,

And worship me as the superior Lord. (PR IV:166-167) 
In Jesus' reply, Milton, true to his hermeneutical principles, sees no need to improve upon Luke's phrasing:

... It is written,

The first of all commandments, 'Thou shalt worship

The Lord thy God and only him shalt serve'. (PR IV:176-177)

In addition to the substantive temptation to rule falsely, Jesus also resists the 'abominable terms' and 'impious condition' that Satan intends to impose before he hands over the authority he claims to have. It is striking that Jesus does not dispute the fact that Satan does have genuine political power:

The kingdoms of the world [Jesus tells Satan] to thee were given! Permitted rather, and by thee usurped (PR IV:182-183)

In the second temptation, then, we have two related components: the temptation to rule falsely and the temptation to pay an abominable price for political power by worshipping one who has power but no true authority. It is plain to all involved in the dialogue, to Jesus and to Satan, to Milton and to those of us who read Milton, that one may do both great harm and great good with political power. History is scattered liberally with false political idols, leaders who prove to be misleaders; but sometimes it is hard, even with hindsight, to tell saints from sinners. Take Charles Stuart: it was Charles' tyranny that led Milton to defend the right of a people to judge and kill their king, but this same king is commemorated in the liturgical calendar of the Church of England as 'Charles, King and Martyr'.

What are we to conclude from Milton's account of the second temptation? Milton does not go so far as to suggest that Christians should disengage from all politics; he does, however, point out that political power is, in the present age, given into Satan's hands. Though this is a view we need not necessarily endorse, given Milton's experience of politics it is one that is understandable. There are, I think, two distinct but related lessons we may draw out. The first is that Christians should concern themselves with the political means they use as well as with the political ends they seek to achieve. Means are not morally neutral in Christian ethics; ends do not justify the means used to achieve them - even when the end achieved is as desirable as peace and prosperity. Milton gives little guidance about how one might discern in practice which political compromises incur morally hazardous debts. International politics often deals 
in compromise: amnesties from justice are given for the sake of a ceasefire; corruption is tolerated for the sake of access to a famine; petty villains are permitted to remain in power in order to keep it from someone worse; one goal is achieved at the expense of another. We do not need history to teach us that all such pacts are Faustian, pacts with a devil who will one day take that which has been promised him. Christians engaging in politics may need to exercise patience with evil and injustice if the only option available to resist them is to use false means. Christians confronting poverty and injustice may find themselves addressed with the question that Milton's Satan, in frustration, addressed to Jesus:

Since neither wealth nor honour, arms nor arts,

Kingdom nor empire, pleases thee, nor aught

By me proposed in life contemplative

Or active, tended on by glory or fame,

What dost thou in the world? (PR IV:368-372)

Christians will bear in mind that political authority, even when held in usurping hands as evil as Satan's, is in some dreadful and mysterious sense permitted by God. Above all, Christians engaged in politics will worship at no other altar than that of the Lord God of Abraham, Isaac, Jacob and Jesus.

The second lesson, therefore, is that Christians can ultimately serve only one Lord: 'Worship the Lord your God, and serve only him' (Luke 4:8). Even love of one's neighbour is not on the same level as love of God but is, rather, an obligation and calling that depends upon and flows from the calling to love and worship God alone. Thus, when a lawyer keen to justify himself to Jesus asks what he must 'do to inherit eternal life', Jesus answered, 'You shall love the Lord your God ... and your neighbour as yourself' (Luke 10:27).

\section{The third temptation}

The third temptation in Luke's Gospel is that Jesus should throw himself from the pinnacle (in Greek, literally 'the wings') of the Temple in Jerusalem, provoking God to save him by commanding his angels to keep him from falling. The first two temptations have established that Jesus trusts God; the devil now tempts him to put that trust to the test, a test Jesus passes by refusing to test God. One of the reasons why most contemporary 
commentators are convinced that the order of the temptations in Matthew's Gospel is original is because it makes better narrative sense that the offer by Satan to Jesus of authority over all the kingdoms of the world is the climax to the temptation story. That may indeed be the case looked at in historical and literary terms, but the Temple has considerable poetic power in the Gospels. Satan has brought Jesus to the place he had, as a boy, described as 'his Father's house' (Luke 2:49); it is the building Jesus would use as an analogy for his own body (John 2:19-21). Luke's choice and Milton's to place the Temple temptation at the climax of the narrative has its own narrative power. Milton in any case deals effectively with any dramatic deficit by expanding significantly the second of Luke's temptations and by allowing the third temptation at the Temple to tell its own story with comparative brevity and simplicity. Milton again takes his lead from Luke's phrasing:

So saying, he caught him up, and, without wing

Of hippogriff, bore through the air sublime,

Over the wilderness and o'er the plain,

Till underneath them fair Jerusalem,

The holy city...

There, on the highest pinnacle, he set

The Son of God ... (PR IV:541-545, 549-550)

The content of the third temptation is that Satan challenges Jesus to put God's promises to the test. Yet in the third temptation it is as much the form the temptation takes as its content that is significant. It has long been understood that the temptation story narrated by Matthew and Luke was very deliberately set against the backdrop of Deuteronomy $6-8$, from which not only the themes of the temptation but the scriptural citations are taken. ${ }^{34}$ It is even likely that in addition to Jesus' recapitulation of the temptation of Adam, Luke may also see in him a recapitulation of the collective person of the people of Israel in the wilderness. It is unsurprising, then, that Satan tempts Jesus by citing passages from the Hebrew Bible or that Jesus answers by also quoting the Hebrew Scriptures. If we take our mind back to De Doctrina Christiana, we may recall that this text largely took the form of collections of biblical quotations on doctrinal themes, introduced and glossed by Milton's commentary. That he could write this book when blind is a testament to his deep knowledge of the Scriptures. In the third temptation it was crucial for Milton that a contrast is drawn between the way the Scriptures are read by Satan and the way they are read by Jesus. Satan speaks the words of scriptural texts that he cannot truly 
understand. When Jesus reads from Scripture, however, he does not merely display acute memory and apologetic skill, his actions incarnate God's Word: Jesus does not simply speak the words of God: he is the Word of God made flesh (John 1:1-18). Jesus' successful out-narration of Satan in the use of the Bible had its basis not in superior intellect, in quicker wits, or in education: Jesus' ability to resist temptation rested on his simple and complete obedience to the will of the Father.

Of all the temptations it is (in Luke's order) the third that therefore most effectively probes Jesus' calling as the Christ (the Messiah) of God. The implication of the anointing by the Spirit of the Son at his Baptism is that the will of Father and Son are one. The third temptation plays on this nerve by teasing out Jesus' unique relationship with his Father. In the farewell discourses in John 13-17 the unity of the Father and the Son is both the sufficient and necessary condition of the unity of the Christian believer with God. Jesus' refusal in the third temptation to countenance the opening up of any distinction between his will and his Father's by tempting God models for the Christian how her will is to be conformed to the will of God. Resisting temptation means seeking the will of God; there is no deeper moral code than this in Christian ethics, no utilitarian calculation of what will achieve the most happiness, no categorical imperative, no natural law buried beneath. To be a Christian in the world is to choose freely to do God's will, and this is not less true when the forum in which one speaks and acts is the public square of politics.

After Jesus' response, Milton tells us that Satan was 'smitten with amazement' and fell precisely in the location where he had tempted Jesus to fall. Jesus is returned to the wilderness where his temptations began and, on a green bank, food fetched by angels from the Tree of Life is spread before him. This is a fine poetic touch, and one that shows great theological intelligence. In overcoming the temptations of Satan to which Adam succumbed, Jesus is returned to paradise, to the Garden from which Eve and Adam were expelled. Jesus' threefold refusal to deny God is, Milton proposes, the foundation for all that follows in the Gospel. In Luke, too, Jesus returns to Galilee'filled with the power of the Spirit' (Luke 4:14) to begin his ministry. None of the Gospel writers place one incident in their narrative after another haphazardly: there is invariably narrative and theological intent. In Luke, Jesus' return to Galilee from the wilderness takes him immediately to the synagogue at Nazareth where, after reading from the prophet Isaiah, Jesus says calmly that the prophet's announcement of God's intention 'to bring good news to the poor ... to 
proclaim release to the captives and recovery of sight to the blind, to let the oppressed go free, to proclaim the year of the Lord's favour' (Luke 4:18-19) is fulfilled in him. The calling of Jesus and of his disciples to 'bring good news to the poor' and to 'let the oppressed go free' is their calling because no one can live by bread alone, because they worship God alone and because they do not put God's will to the test.

\section{Conclusion}

One sure way of avoiding temptation is to do nothing. But, for the Christian, truth is not simply something one thinks but something one does, for 'those who do what is true come to the light' (John 3:21). And where the believer does truth, temptation must always follow. This is because 'the action of truth awakens falsehood from its inertia and causes it to defend itself; that is the meaning of the temptation of the saints. ${ }^{\prime 35}$

One interpretation of the three temptations Jesus faced, with which Milton was certainly familiar, was that they relate to his threefold office as the Christ of God as Prophet, Priest and King. In this interpretation, the first temptation in Luke's order related to his prophetic office, the second to his kingly office, and the third (because it took place at the Temple) to his priestly office. I have tried to show that it is possible to see each temptation as an increasingly intense examination of Jesus' identity as it is worked out in a widening range of social and political contexts from Israel to Rome and from the company of the disciples to the company of the angels. In the temptations, Satan seeks out the fissures between what Jesus wills and what God wills, but finds none. Milton knew that Satan continues to test Christians in the same ways: he knew it because he had experienced it. He had seen how the expected paradise of the Commonwealth had been lost, and found himself asking how it might be regained. Reading the Gospels closely, he poetically reconstructed the temptations of Jesus to show that politics, no more than temptation, can be avoided. Satan continues to use the natural human need for food, the natural human desire for peace, justice and prosperity, and the natural human desire for political certainties to test Christians. Jesus' responses to Satan's temptations show that the only way through is to 'strive first for the kingdom of God and his righteousness, and these things will be given to you as well' (Matthew 6:33). 


\section{Notes}

1. Richey et al. 2010, p. 336.

2. Dietrich Bonhoeffer, 'Essay about Protestantism in the United States', in Schultz and Barnett 2005, p. 456.

3. I have explored this at greater length elsewhere: see Plant 2013.

4. Kazantzakis 1960. The novel was made into a film in 1988 by Martin Scorsese, with Willem Dafoe in the role of Jesus.

5. Crace 1998. The title is a clever wordplay on ' 40 days'.

6. Paradise Regained was first published as Paradise Regain'd. A Poem. In IV Books. To which is added Samson Agonistes, printed by'JM' (John Macock). It was advertised and licensed in 1670 but not printed until the following year. Ken Simpson speculates that the delay may have been the result of concerns about Milton's Nonconformity following the passing of the Second Conventicle Act in 1670 (Simpson 2007, p. 187, n. 1). All citations from Milton's poems are taken from John Carey and Alastair Fowler (eds), The Poems of John Milton (London: Longmans, Green and Co. Ltd., 1968), hereafter: Milton, Poems. References are to page numbers and line numbers in this edition and, in the longer poems, to page, book and line numbers.

7. Milton, Poems, pp. 329-330. The editors take note of doubts about the date of this poem's composition, fixing on the probable date of 1652 since, according to William Parker, Milton's biographer, the poet considered himself practically blind by November 1651 (see Parker 1968).

8. Sonnet XVI, Milton, Poems, p. 330:3-4.

9. Parker 1968, p. 352.

10. The full title of the pamphlet was The Tenure of Kings and Magistrates: proving, that it is lawful, and hath been held so through all ages, for any, who have the power, to call to account a tyrant, or wicked king, and after due conviction, to depose, and put him to death, if the ordinary magistrate have neglected, or declined to do it. And that they, who of late, so much blame deposing, are the men who did it themselves. See Parker 1968, p. 347.

11. Parker 1968, p. 347.

12. See Hill 1977, pp. 415-416.

13. Parker 1968, p. 568.

14. Parker 1968, p. 591.

15. The claim was made in Toland's 'Life of John Milton', prefixed to a 1698 edition of Milton's prose works; cited by Dzelzainis 2009, p. 547.

16. Fish 1998, p. iv.

17. Examples of the extensive literature on Milton's theological views include, in the order in which they were published, Empson 1965; Patrides 1966; Danielson 1982; Lieb 2006; Simpson 2007.

18. The book was translated by Charles Sumner and published as A Treatise on Christian Doctrine Compiled from the Holy Scriptures by John Milton; see Milton 1825.

19. Milton 1825, p. 465. 
20. Milton 1825, p. 466.

21. Milton 1825, pp. 468-469.

22. Milton 1825, p. 471. Milton does allow that, in passages in the Old Testament, there is 'sometimes a compound of the historical and the typical', that is, a plain historical sense and an allegorical or typological sense.

23. Simpson 2007, especially pp. 54-105.

24. Milton 1825 p. 471.

25. Milton 1825, p. 472 , my italics.

26. Milton 1825, p. 472.

27. Knoppers 2009, p. 584.

28. Paradise Lost, Book I:25-26.

29. See, eg, Roberts and Donaldson 2004, p. 549.

30. For a thorough historical-critical analysis of treatments of New Testament texts relating temptations of Jesus, see Gibson 1995, chapters 1-3. See also Carroll 2012, pp. 100-105.

31. A passive participle of peivazō.

32. See Thayer 1901, pp. 498-499, and Friedrich 1968, pp. 23-36.

33. Chrysostom 1975, Homily XIII on Matthew 4:1.

34. Gibson 1995, pp. 85-90.

35. Simone Weil, cited by Perrin and Thibon 2003, p. 85.

\section{Bibliography}

\section{Exegetical resources}

Biblical citations are from the New Revised Standard Version, Anglicized Edition, Oxford: Oxford University Press, 1998.

Friedrich, G. 1968. Theological Dictionary of the New Testament, vol. VI, trans. Bromiley, G. Grand Rapids, MI: Eerdmans.

Thayer, J. H. 1901. A Greek-English Lexicon of the New Testament. 4th edn, Edinburgh: T \& T Clark.

\section{Texts by John Milton}

Carey, John and Fowler, Alastair. 1968, The Poems of John Milton. London: Longmans, Green and Co. Ltd.

Milton, John (?). 1825. A Treatise on Christian Doctrine Compiled from the Holy Scriptures by John Milton, trans Charles Sumner. Cambridge: Cambridge University Press.

\section{Other texts cited}

Barnett, Victoria J. (ed.). 2005. Dietrich Bonhoeffer: Theological Education Underground: 1937-1940, Minneapolis, MN: Fortress Press.

Chrysostum, St John. 1975. St Chrysostom Homilies on the Gospel of Matthew, Nicene and Post Nicene Fathers Series 1, volume X. Grand Rapids, MI: Eerdmans.

Carroll, John T. 2012. Luke: A Commentary. Louisville, KY: Westminster John Knox Press. Crace, Jim. 1998. Quarantine. London: Penguin. 
Danielson, D. R. 1982. Milton's Good God: A Study in Literary Theodicy. Cambridge: Cambridge University Press.

Dzelzainis, Martin. 'The Politics of Paradise Lost', in McDowell, Nicholas and Smith, Nigel (eds). 2009. The Oxford Handbook of John Milton. Oxford: Oxford University Press. Empson, William. 1965. Milton's God. Westport, CT: Greenwood Press.

Fish, Stanley. 1998. Surprised by Sin: The Reader in 'Paradise Lost'. 2nd edn, Cambridge, MA: Harvard University Press.

Gibson, Jeffrey B. 1995. The Temptations of Jesus in Early Christianity. Sheffield: Sheffield Academic Press.

Hill, Christopher. 1977. Milton and the English Revolution. London: Faber and Faber. Kazantzakis, Nikos. 1960, The Last Temptation of Christ. New York: Simon \& Schuster. Knoppers, Laura Lunger. '"England's Case": Contexts of the 1671 Poems', in McDowell, Nicholas and Smith, Nigel (eds). 2009. The Oxford Handbook of Milton. Oxford: Oxford University Press.

Lieb, Michael. 2006. Theological Milton: Deity, Discourse and Heresy in the Milton Canon. Pittsburgh, PA: Duquesne University Press.

Parker, William R. 1968, Milton: A Biography, Volume l: The Life. Oxford: Oxford University Press.

Patrides, C. A. 1966. Milton and the Christian Tradition. Oxford: Oxford University Press.

Plant, Stephen. 'Methodism and Politics: Mapping the Political on the Methodist Genome', in Gibson, W., Forsaith, P. and Wellings, M. (eds). 2013. The Ashgate Research Companion to World Methodism. Farnham: Ashgate, pp. 346-363.

Perrin, J. M. and Thibon, G. 2003. Simone Weil as We Knew Her. London: Routledge.

Roberts, A. and Donaldson, J. (eds). 2004. 'Irenaeus against Heresies', in Ante-Nicene Fathers, Volume 1. Peabody, MA: Hendrickson Publishers.

Rowe, Kenneth E. and Scmidt, Jean Miller (eds). 2010. The Methodist Experience in America: A History, Volume 1. Nashville TN: Abingdon Press.

Simpson, Ken. 2007. Spiritual Architecture and Paradise Regained: Milton's Literary Ecclesiology. Pittsburgh, PA: Duquesne University Press. 